\title{
Optogenetic Dissection of the Basal Forebrain Neuromodulatory Control of Cortical Activation, Plasticity, and Cognition
}

\author{
[DShih-Chieh Lin, ${ }^{1}$ Ritchie E. Brown, ${ }^{2}$ Marshall G. Hussain Shuler, ${ }^{3}$ (C) Carl C.H. Petersen, ${ }^{4}$ and Adam Kepecs ${ }^{5}$ \\ ${ }^{1}$ National Institute on Aging, National Institutes of Health, Baltimore, Maryland 21224, ${ }^{2}$ Department of Psychiatry, Veterans Administration Boston \\ Healthcare System and Harvard Medical School, Brockton, Massachusetts 02301, ${ }^{3}$ Department of Neuroscience, Johns Hopkins University, Baltimore, \\ Maryland 21205, ${ }^{4}$ Laboratory of Sensory Processing, Brain Mind Institute, Federal Institute of Technology of Lausanne, CH-1015 Lausanne, Switzerland, \\ and ${ }^{5}$ Neuroscience, Cold Spring Harbor Laboratory, Cold Spring Harbor, New York 11724
}

The basal forebrain (BF) houses major ascending projections to the entire neocortex that have long been implicated in arousal, learning, and attention. The disruption of the BF has been linked with major neurological disorders, such as coma and Alzheimer's disease, as well as in normal cognitive aging. Although it is best known for its cholinergic neurons, the BF is in fact an anatomically and neurochemically complex structure. Recent studies using transgenic mouse lines to target specific BF cell types have led to a renaissance in the study of the $\mathrm{BF}$ and are beginning to yield new insights about cell-type-specific circuit mechanisms during behavior. These approaches enable us to determine the behavioral conditions under which cholinergic and noncholinergic BF neurons are activated and how they control cortical processing to influence behavior. Here we discuss recent advances that have expanded our knowledge about this poorly understood brain region and laid the foundation for future cell-type-specific manipulations to modulate arousal, attention, and cortical plasticity in neurological disorders.

Key words: nucleus basalis; GABAergic; reinforcement; reward timing; cortical state; motivational salience

\section{Significance Statement}

Although the basal forebrain is best known for, and often equated with, acetylcholine-containing neurons that provide most of the cholinergic innervation of the neocortex, it is in fact an anatomically and neurochemically complex structure. Recent studies using transgenic mouse lines to target specific cell types in the basal forebrain have led to a renaissance in this field and are beginning to dissect circuit mechanisms in the basal forebrain during behavior. This review discusses recent advances in the roles of basal forebrain cholinergic and noncholinergic neurons in cognition via their dynamic modulation of cortical activity.

\section{Introduction}

The basal forebrain (BF) contains multiple major ascending arousal systems that promote wakefulness, awareness, and corti-

Received July 6, 2015; revised Sept. 1, 2015; accepted Sept. 2, 2015.

This research was funded in part by the Veterans Administration, the National Institute on Aging Intramural Research Program, National Institute of Neurological Disorders and Stroke Grants R01 NS075531, NS088661, and R21 NS093000, National Institute of Mental Health Grants R01 MH039683 and MH093665, National Heart, Lung, and Blood Institute Grant R01 HL095491, the John Merck and McKnight Foundations, the European Research Council, the Swiss National Science Foundation, and a National Alliance for Research on Schizophrenia and Depression Young Investigator Award.

The contents of this article do not represent the views of the U.S. Department of Veterans Affairs or the United States Government.

The authors declare no financial conflicts of interest.

Correspondence should be addressed to Shih-Chieh Lin, Neural Circuits and Cognition Unit, Laboratory of Behavioral Neuroscience, National Institutes on Aging, National Institutes of Health, 251 Bayview Boulevard, Suite 100, 9C220, Baltimore, MD 21224. E-mail: shih-chieh.lin@nih.gov.

DOI:10.1523/JNEUROSCI.2590-15.2015

Copyright $\odot 2015$ the authors $\quad 0270-6474 / 15 / 3513896-08 \$ 15.00 / 0$ cal low-voltage fast activity (Moruzzi and Magoun, 1949; Semba, 2000; Zaborszky, 2002; Jones, 2003, 2004; Brown et al., 2012; Zaborszky et al., 2015). The BF has also long been implicated in cognitive functions, including attention, learning, and motivational salience (DeLong, 1971; Richardson and DeLong, 1990; Wilson and Rolls, 1990a; Voytko et al., 1994; Voytko, 1996; Lin and Nicolelis, 2008). The degeneration of the BF is an early event in Alzheimer's disease (Whitehouse et al., 1982; Grothe et al., 2012) and forms of dementia (Cummings and Benson, 1984) and is associated with normal cognitive aging (Gallagher and Colombo, 1995). Deep brain stimulation targeting the BF is being evaluated as a novel therapy for dementia-related disorders (Freund et al., 2009; Hescham et al., 2013; Salma et al., 2014).

The BF is an extended structure situated at the base of the brain and classically defined by the presence of clusters of large cholinergic neurons (Meynert, 1872), which are found in the medial septum 
(Ch1), the vertical (Ch2) and horizontal (Ch3) limbs of the diagonal band, as well as in the substantia innominata/nucleus basalis (NB) (Ch4; Mesulam et al., 1983). These regions provide ascending projections to the hippocampus, thalamus (Parent et al., 1988; Jourdain et al., 1989; Bickford et al., 1994; Gritti et al., 1998), amygdala (Unal et al., 2015), and neocortex (Zaborszky et al., 2015), as well as descending projections to the hypothalamus (Gritti et al., 1994). Here we focus on recent optogenetic studies conducted by the authors that targeted the $\mathrm{Ch} 3 / \mathrm{Ch} 4$ regions and their projections to the neocortex. We note that other recent studies also addressed postsynaptic cell-type-specific mechanisms of cholinergic activation in the cortex (Arroyo et al., 2012; Bennett et al., 2012; Saunders et al., 2015) and important subcortical projections (Unal et al., 2015) that our review does not cover.

Although the BF is best known for, and often equated with, acetylcholine-containing neurons that provide most of the cholinergic innervation of the neocortex (Jones, 2004), it actually contains projection neurons with a diversity of neurotransmitters. In addition to cholinergic neurons, the $\mathrm{BF}$ houses two other, parallel projection systems to the cortex, one releasing GABA and the other glutamate as their main neurotransmitter (Mesulam and Van Hoesen, 1976; Brashear et al., 1986; Freund and Gulyás, 1991; Freund and Meskenaite, 1992; Gritti et al., 1993; Hur and Zaborszky, 2005; Henny and Jones, 2008). The anatomical heterogeneity and cell-type diversity of the BF have hampered research into how it functions. The availability of new transgenic mouse lines to specifically target cholinergic, GABAergic, and glutamatergic $\mathrm{BF}$ projections is rapidly changing the field (Hippenmeyer et al., 2005; Rossi et al., 2011; Vong et al., 2011; Zhao et al., 2011). When used together with other technological advances, such as optogenetics and pharmacogenetics, these new mouse lines have allowed researchers to perform critical experiments that could only be dreamt about until recently (Boyden et al., 2005; Zhang et al., 2007; Nawaratne et al., 2008).

In this review, we aim to provide an overview of recent advances grouped around three major topics. First, although the role of the $\mathrm{BF}$ in cognitive functions has long been associated with its cholinergic modulation, until recently it has not been possible to determine when and how cholinergic BF neurons are specifically activated in behavior. Second, although the study of the BF has traditionally focused on cholinergic neurons, cortical projections from the BF contain equally if not more prominent noncholinergic components, and their functions are poorly understood. Third, the circuit mechanisms by which cholinergic and noncholinergic BF neurons dynamically modulate cortical activity to mediate cognitive functions remain unclear. Together, these new studies advance our understanding of the $\mathrm{BF}$ and begin to reveal the rich temporal dynamics and diverse functions served by distinct components of this neuromodulatory hub. We begin with new studies focused on the BF cholinergic projection and then move on to discuss noncholinergic BF neurons.

\section{BF cholinergic neurons are activated by reward and punishment with remarkable speed}

Most of our knowledge about central cholinergic function in cognition has come from lesions and pharmacological studies (Everitt and Robbins, 1997; McGaughy et al., 2000; Hasselmo and Sarter, 2011). However, when are cholinergic neurons recruited during behavior and what cognitive variables do they signal? Progress in answering this long-standing question has been stalled by the lack of tools for cell-type-specific recordings. A handful of identified cholinergic neurons have been recorded across sleep-wake states using a juxtacellular approach with post hoc identification, a challenging technique that is difficult to combine with behavior (Lee et al., 2005; Hassani et al., 2009). Unfortunately, cholinergic neurons cannot be identified definitively using extracellular recordings based on anatomical landmarks, pharmacological approaches, or distinct action potential waveforms. As a consequence, until recently, there have been no recordings of identified BF cholinergic neurons in behaving animals. This challenge was taken up in a recent study that used optogenetics-assisted celltype identification to extracellularly record cholinergic neurons (Hangya et al., 2015).

To determine which aspects of cognition cholinergic activity might support, these authors trained mice on an auditory detection task requiring sustained attention. Correct responses were rewarded with a drop of water, whereas false-alarm responses triggered a mild puff of air directed to the face as punishment. This task was designed to test the long-standing hypothesis that the cholinergic system is involved in attentional functions on a fast timescale (Everitt and Robbins, 1997; Sarter et al., 2005, 2009; Herrero et al., 2008). Sustained attention might fluctuate in time, and its momentary level is expected to modulate behavioral performance, such as accuracy and reaction time (Coull and Nobre, 1998; Barnes and Jones, 2000). Thus, attentional modulation can be defined operationally as neural activity before stimulus onset that predicts facets of behavior, such as reaction time or accuracy. Surprisingly, not the cholinergic but the activity of a population of unidentified neurons predicted reaction time and performance accuracy, behavioral measures classically associated with attention. These results supported the view that the BF serves attentional functions, albeit controlled by some noncholinergic neurons.

To motivate behavioral performance, mice were rewarded and punished based on their choices, which enabled the authors to test whether cholinergic responses are related to reinforcers. Indeed, nearly all cholinergic neurons responded with strong, short-latency activation to primary reinforcers: water reward and air-puff punishment. Punishment elicited uniform and reliable activation at remarkably short latencies $(18 \pm 2 \mathrm{~ms})$ in cholinergic neurons. Reward-elicited responses were larger when the signal-to-noise ratio of the preceding auditory stimuli was lower. These responses were consistent with a model according to which graded reinforcement surprise recruits cholinergic neurons. The remarkable speed and precision of cholinergic activation provides a key piece of evidence complementing in vitro studies showing that the millisecond timing of acetylcholine can control the strength and even the sign of plasticity at hippocampal synapses (Gu and Yakel, 2011; Gu et al., 2012). In addition, cholinergic neurons appear to recruit specific subtypes of cortical inhibitory interneurons that generate disinhibition (Letzkus et al., 2011).

Interestingly, the response properties of cholinergic neurons were similar across two different nuclei within the BF, the prefrontally projecting horizontal diagonal band $(\mathrm{Ch} 3)$ and the auditory cortex projecting NB (Ch4), despite the fact that these nuclei are often implicated in different functions and have a different topography of cortical projections (Zaborszky et al., 2015). These results reveal that the BF cholinergic system broadcasts a precisely timed signal to large areas of the brain and thereby could support learning and plasticity as a reinforcement signal (Hangya et al., 2015), as suggested by previous nonspecific electrical stimulation studies (Kilgard and Merzenich, 1998). 


\section{A BF cholinergic signal conditions reward timing activity in the primary visual cortex}

Converging evidence supporting the idea that $\mathrm{BF}$ cholinergic neurons convey a reinforcement signal comes from studies of reward timing activity in the primary visual cortex (V1) of rodents. Reward timing activity in V1 emerges as a consequence of pairing visual stimuli with delayed reward, leading to stimulusevoked activity in V1 that predicts the timing of expected future reward (Shuler and Bear, 2006; Zold and Hussain Shuler, 2015). Thus, reward timing activity exemplifies a core function of the brain: predicting the timing of future events of behavioral importance based on past experience. This ability to appreciate the predictive qualities of environmental cues affords a means by which the organism may subsequently evaluate the relative worth of options, inform the timing of future actions, and govern future learning in response to changes in the experienced environment. Indeed, visually cued, interval timing activity in V1 has been shown to report the target interval to reward, informing the decision of when to time the action on a trial-by-trial basis (Namboodiri et al., 2015).

A formal reinforcement-based model was proposed to address how reward timing activity may form within V1 (Gavornik et al., 2009; Huertas et al., 2015). A key aspect of the formal computational model is the provision of a reinforcement signal conveying behavioral outcome. Indeed, Weinberger and colleagues have long advanced the hypothesis that BF cholinergic innervation conveys a signal conducive to engendering physiological memories in cortex. Their programmatic investigation has demonstrated that a tone paired with direct acetylcholine application to the auditory cortex or NB electrical stimulation results in receptive field modification toward the paired frequency, mimicking that induced by behavioral conditioning, an effect blocked by cortical application of atropine (Metherate and Weinberger, 1989; Bakin and Weinberger, 1996; Miasnikov et al., 2001). Furthermore, conditioning by NB pairing leads to behavioral associative memories (McLin et al., 2002) by acting as a teaching, rather than as a motivational, signal (Miasnikov et al., 2008). Given these and related observations (Bear and Singer, 1986; Gu and Singer, 1989; Froemke et al., 2007), BF cholinergic input was postulated as a potential signal carrying a reinforcement signal affecting plasticity in V1. Therefore, to test the necessity of the cholinergic system for learning reward timing activity, Chubykin et al. (2013) selectively lesioned cholinergic BF input to V1 via injections of 192-IgG-saporin into V1 and assessed whether new cue-reward delays could be learned and expressed neurally within V1. This study showed that BF cholinergic innervation to V1 is indeed required for reward timing activity to be learned in V1. Importantly, cholinergic innervation was not necessary for already learned reward timing to be expressed.

To test the sufficiency of BF cholinergic input for reward timing activity in the visual cortex, another study examined directly whether $\mathrm{BF}$ innervation of $\mathrm{V} 1$ in general, and cholinergic innervation of $\mathrm{V} 1$ in particular, is sufficient to condition cued-interval timing activity mimicking reward timing activity as observed after behavioral conditioning (Liu et al., 2015). By optogenetically driving BF input within $\mathrm{V} 1$ at fixed temporal delays after predictive visual cues, Liu et al. demonstrated that cue-evoked "reward" timing activity is indeed elicited by selective activation of BF input. Their results also demonstrated that optogenetically entrained timing activity in V1 can be bidirectionally tuned to represent new conditioning intervals and is subject to experiencedependent refinement. Interestingly, the distributions of neural reports to given delays exhibit a scale invariance with respect to the delay. Such multiplicative scaling may be a neural correlate of the scalar timing property - a version of Weber's law in the time domain - wherein the distributions of behaviorally timed responses are superimposable after multiplicative scaling (Gibbon, 1977). Finally, by conditioning visually evoked responses with selective activation of cholinergic fibers within V1, Liu et al. advanced the case that cholinergic innervation within V1 is indeed sufficient for cued interval-timing activity, in addition to it being necessary (Liu et al., 2015). Together with the study by Hangya et al. (2015) showing that BF cholinergic neurons respond acutely to behavioral outcome (reviewed above), these studies advance the case that $\mathrm{BF}$ cholinergic innervation acts as a reinforcement signal shaping cortical circuits to generate behaviorally relevant activity.

\section{BF cholinergic signaling controls cortical states during whisking}

In addition to its role in plasticity, the cholinergic BF projection to the cortex is also involved in modulating cortical network state (Jones, 2004). Cholinergic input to the cortex has long been considered to act as a global activating system (Buzsaki et al., 1988; Metherate et al., 1992; Jones, 2005; Brown et al., 2012; Pinto et al., 2013), but until recently, there were no direct measurements of cholinergic signaling and cortical state changes on rapid timescales with behavioral relevance in awake mice.

Cortical states in the primary somatosensory barrel cortex (S1) in awake animals shift between quiet wakefulness and active whisking. During quiet wakefulness in head-restrained mice, slow, large-amplitude fluctuations in membrane potential of layer 2/3 excitatory neurons in S1 are common. These fluctuations are highly synchronized in nearby neurons and can be observed readily in the local field potential and the electroencephalogram (Poulet and Petersen, 2008). However, when mice are actively exploring their immediate environment by rhythmically moving their whiskers backwards and forwards, the slow membrane potential fluctuations are suppressed. This active cortical state is characterized by depolarized membrane potential, decreased membrane potential variance, and reduced correlation of membrane potential fluctuations in nearby neurons (Poulet and Petersen, 2008).

Sensory processing depends strongly on cortical state, with smaller and more localized responses to whisker deflection during the active desynchronized cortical state (Ferezou et al., 2007). The active cortical state appears to be generated by internal brain mechanisms, because it is essentially unaffected by cutting the sensory nerves. Key determinants of the active whisking cortical state include increases in thalamic (Poulet et al., 2012) and cholinergic (Eggermann et al., 2014) input to the barrel cortex. Firing rates in the somatosensory thalamus increase strongly during whisking compared with quiet wakefulness, and this increased glutamatergic input drives depolarized and desynchronized activity in S1 (Poulet et al., 2012). Inactivation of the thalamus increases slow, large-amplitude fluctuations in membrane potential during quiet wakefulness, but during whisking after thalamic inactivation, $\mathrm{S} 1$ is hyperpolarized with low membrane potential variance (Poulet et al., 2012).

A recent study found that the hyperpolarized state of the neocortex during active whisking after thalamic inactivation appears to be mediated by release of acetylcholine by neurons located in the BF and projecting to S1 (Eggermann et al., 2014). Calcium signals in cholinergic axons in S1 are prominent during whisking, suggesting that acetylcholine is being released (Eggermann et al., 2014). Injection of pharmacological antagonists of cholinergic 
receptors into $S 1$ blocked the whisking-related hyperpolarization of the cortex after thalamic inactivation (Eggermann et al., 2014), with the strongest effects mediated by muscarinic antagonists. Finally, optogenetic stimulation of cholinergic neurons in the BF could mimic the effects of whisking on membrane potential dynamics in S1, and these effects could also be blocked by local injection of cholinergic antagonists (Eggermann et al., 2014).

Therefore, these results demonstrate prominent cholinergic signals during whisking in $\mathrm{S} 1$ and suggest that the active state of mouse $\mathrm{S} 1$ during whisking is driven by at least two different signals: increased thalamic firing and increased cholinergic signaling. The released acetylcholine suppresses slow spontaneous activity accompanied by hyperpolarization during whisking, which likely counteracts the increased thalamic input during whisking (Poulet et al., 2012). Cholinergic input to S1 might also contribute to the reduced amplitude and spread of whisker-deflection-evoked sensory responses during whisking compared with quiet wakefulness (Crochet and Petersen, 2006; Ferezou et al., 2007).

\section{Control of cortical arousal by parvalbumin-containing GABAergic BF neurons}

In addition to cholinergic neurons, there are multiple other types of cortically projecting neurons in the BF, many of which, like the cholinergic neurons described in the previous sections, exhibit increases in activity associated with cortical activation (Hassani et al., 2009). Among these, GABAergic neurons are particularly numerous and important in behavioral state control (Brown and McKenna, 2015; Kim et al., 2015). In fact, in mice, there are approximately seven times (3.9-12 times depending on the BF subregion) as many GABAergic neurons as cholinergic neurons (McKenna et al., 2013; Yang et al., 2014). A significant minority of these BF GABAergic neurons are long-range projection neurons with targets in the neocortex, hippocampus, thalamus, and lateral hypothalamus (Freund and Meskenaite, 1992; Gritti et al., 1994, 1997, 2006; Henny and Jones, 2008; McKenna et al., 2013). A subset of the neocortically projecting BF GABAergic neurons contains the calcium-binding protein parvalbumin (PV) (Gritti et al., 2003). In mice, PV is contained in approximately onequarter of large $(>20 \mu \mathrm{m})$, putative long-range projecting, GABAergic neurons (McKenna et al., 2013). Other neocortically projecting BF GABA neurons express the potassium channel Kv2.2 (Hermanstyne et al., 2010) or the neurokinin-3 receptor (Furuta et al., 2004).

In vitro whole-cell recordings in GAD67-GFP knock-in mice or PV-tdTomato mice allowed the first characterization of the intrinsic membrane properties of identified GABAergic and PV neurons (McKenna et al., 2013). These recordings revealed many similarities but also important differences between BF GABAergic/PV projection neurons and cortical fastspiking PV interneurons. Like cortical PV interneurons, BF GABAergic/PV projection neurons are very fast firing, with brief action potentials and electrical coupling (McKenna et al., 2013). However, unlike their cortical counterparts, they are spontaneously active in the absence of injected current and exhibit prominent hyperpolarization-activated cation currents that resist prolonged hyperpolarization and may play a role in promoting the rhythmic cluster/burst activity of identified BF GABAergic and PV neurons observed in vivo (Duque et al., 2000; Hassani et al., 2009).

What effect do cortically projecting BF GABAergic neurons have on cortical function? Clues to the answer of this question came from juxtacellular recordings in vivo that showed that a significant minority of identified GABAergic neurons exhibit fast firing during wakefulness and rapid eye movement sleep (Hassani et al., 2009), as well as from anterograde tracing studies that showed that BF GABAergic neurons preferentially target cortical interneurons, including fast-firing PV neurons involved in cortical gamma oscillations (Freund and Meskenaite, 1992). Thus, it was postulated that BF GABAergic neurons may exert a state-dependent control over cortical gamma oscillations.

A recent study (Kim et al., 2015) tested this hypothesis using an optogenetic approach targeting the subset of BF GABAergic neurons containing PV. Indeed, selective optical stimulation of BF PV neurons preferentially enhanced cortical EEG power in the gamma range, whereas optical inhibition reduced the power of cortical $40 \mathrm{~Hz}$ oscillations induced by a $40 \mathrm{~Hz}$ auditory stimulus train (Kim et al., 2015). Thus, although many GABAergic neurons in the BF are sleep active/sleep promoting (Hassani et al., 2009), a significant subset project to the cortex and promote the fast gamma-band activity typical of conscious states, likely through entrainment of the firing of cortical interneurons. Cholinergic neurons strongly excite BF GABAergic and PV neurons through local release of acetylcholine (Yang et al., 2014). Thus, under normal conditions, the BF cholinergic and GABAergic systems likely work synergistically to generate cortical activation and promote wakefulness.

Studies of BF noncholinergic neurons in rodents have opened up a new vista in our understanding of BF control of cortical activation. Given that GABAergic and PV neurons are similarly present in primates (Walker et al., 1989; Côté et al., 1991), a challenge for the future will be to determine whether these are also cortical-projecting neurons with similar functions and apply this knowledge to the treatment of human disorders affecting the BF, such as coma and Alzheimer's disease.

\section{Another group of noncholinergic BF neurons encodes motivational salience and modulates the speed of decision making}

In addition to cholinergic neurons and PV-containing GABAergic neurons described above, another group of presumably noncholinergic BF neurons has been studied extensively in recent years (Lin et al., 2006; Lin and Nicolelis, 2008; Avila and Lin, 2014a,b; Nguyen and Lin, 2014). This population of BF neurons shares homogeneous physiological properties, including low tonic baseline firing rates $(<10 \mathrm{~Hz})$ and intermittent phasic bursting activity that is highly correlated among neurons in this group (Lin et al., 2006; Avila and Lin, 2014b). Their large, broad and complex action potential waveforms (Avila and Lin, 2014b) and short latencies in modulating cortical activity (Nguyen and Lin, 2014) are consistent with these neurons being long-range projection neurons. These neurons represent a distinct population in the BF that encodes reward and motivational salience information using phasic bursting responses (Lin and Nicolelis, 2008; Avila and Lin, 2014b; Nguyen and Lin, 2014) and have been referred to as "salience-encoding" or "bursting" BF neurons. The bursting BF neurons are unlikely to be the cholinergic neurons (Lee et al., 2005; Hangya et al., 2015) or PV-containing GABAergic neurons (Kim et al., 2015) because, in addition to differences in firing properties, the bursting BF neurons do not modulate their average firing rates across sleep-wake states (Lin et al., 2006; Lin and Nicolelis, 2008). These observations suggest that salience-encoding $\mathrm{BF}$ neurons represent yet another group of noncholinergic and non-PV BF neurons whose neurochemical identity remains to be determined. 
The response profile of this group of $\mathrm{BF}$ neurons has, in fact, been described widely in the BF literature. Among the first studies of the substantia innominata region in behaving monkeys, DeLong (1971) described how BF neurons have low tonic firing rates and respond to reward and reward-predicting cues. Such response profiles have since been characterized widely in behaving monkeys (Richardson and DeLong, 1990, 1991; Wilson and Rolls, 1990a,b) and rodents (Tindell et al., 2005, 2009; Smith et al., 2011; Thomson et al., 2014; Tingley et al., 2014). Despite the prevalence of this neuronal population in BF recording studies, this activity pattern has been mostly misinterpreted in the literature as representative of $\mathrm{BF}$ cholinergic neurons.

The encoding of motivational salience by bursting responses of noncholinergic neurons appears to play a key role in some decision-making processes. The BF bursting activity is not required for sensory detection because clearly perceptible sensory cues do not elicit any BF response before associative learning (Lin and Nicolelis, 2008). Rather, as demonstrated in an auditory near-threshold detection task, the BF bursting activity is tightly correlated with and potentially enables the animal to properly respond to a detected cue based on its motivational salience (Lin and Nicolelis, 2008). These observations led to the hypothesis that BF bursting activity serves to enhance the cortical representations of detected stimuli for the purpose of reinforcementguided behavior (Lin and Nicolelis, 2008). In support of this hypothesis, stronger BF bursting responses to motivationally salient cues are tightly coupled with, and causally linked to, faster and more precise decision speed (Avila and Lin, 2014a). Furthermore, the recruitment of the $\mathrm{BF}$ motivational salience signal enhances processing in the frontal cortex by generating an eventrelated potential response (Nguyen and Lin, 2014). Therefore, the BF motivational salience signal likely serves as a gainmodulation mechanism to modulate the speed of the decisionmaking process, which facilitates behavioral responding to sensory cues based on their motivational, but not perceptual, salience.

These findings highlight the need to determine the neurochemical identity of salience-encoding BF neurons to test whether they correspond to BF glutamatergic projections to the cortex (Hur and Zaborszky, 2005) or, alternatively, BF GABAergic projections that preferentially innervate cortical interneurons and may enhance cortical processing through disinhibition (Freund and Gulyás, 1991; Freund and Meskenaite, 1992; Henny and Jones, 2008).

\section{Conclusions}

Classic studies of the BF neuromodulatory system using selective cholinergic immunotoxic lesions, pharmacology, and electrical stimulation, among other techniques, have been of great importance in relating $\mathrm{BF}$, at the mechanistic level, to cortical activation and plasticity and, at the behavioral level, to arousal, learning, and attention (Metherate et al., 1992; Everitt and Robbins, 1997; McLin et al., 2002; Sarter et al., 2005; Disney et al., 2007; Herrero et al., 2008; Goard and Dan, 2009; Baxter and Bucci, 2013). New techniques for genetically targeting distinct neuronal types, observing their activity, and manipulating them using optogenetic tools enables entirely new types of experiments that have revitalized the field. We can now record the activity of specific types of projection neurons during behavior, and then, informed by these observations, we can attempt to "reinject" the patterns of activity observed. These new tools are allowing the field to test directly the causal role of distinct pathways using gain- and loss-of-function experiments.
After decades of focus on the putative general arousal role of cholinergic BF neurons, recent studies exploiting cell-typespecific targeting and optogenetics reviewed here are beginning to provide novel insights on the behavioral function of cholinergic neurons and their circuit-level mechanism, as well as revealing the functional significance of diverse noncholinergic neuronal populations in the BF. These results show that cholinergic $\mathrm{BF}$ neurons broadcast a fast reinforcement signal to the cerebral cortex (Hangya et al., 2015) that is capable of inducing plastic changes in V1 to produce a reward timing signal (Chubykin et al., 2013; Liu et al., 2015), as well as powerfully modulating the membrane dynamics in cortical circuits to generate active brain states (Eggermann et al., 2014). Conversely, noncholinergic BF neurons appear to play equally powerful roles in enhancing cortical activity, especially in the frontal cortex, through generating gamma oscillations (Kim et al., 2015) and an event-related potential response (Nguyen and Lin, 2014). The results reviewed here suggest that both cholinergic and noncholinergic BF neurons enhance cortical activity, but the timing of their modulation during behavior may differ: cholinergic BF neurons primarily respond to reinforcers (Hangya et al., 2015) whereas subsets of noncholinergic BF neurons respond phasically to motivationally salient cues that predict reinforcement (Lin and Nicolelis, 2008; Avila and Lin, 2014a) and correlate with operational measures of attention (Hangya et al., 2015). Therefore, cholinergic and noncholinergic BF neurons might play complementary and synergistic functions in arousal and cognition. Together, these studies are rapidly changing the face of the $\mathrm{BF}$ neuromodulatory system away from a monolithic and slow cholinergic modulatory action and begin to unveil the full rapid temporal dynamics of heterogeneous elements in the BF circuit.

These results mark just the beginning of a new era in the study of the $\mathrm{BF}$, and much remains to be explored in this anatomically and neurochemically heterogeneous region. For instance, cholinergic and noncholinergic neurons are segregated topographically, each neuron projecting to a relatively small cortical region (Wu et al., 2014; Zaborszky et al., 2015); thus, it will be important to determine whether there are conditions under which certain subpopulations are selectively recruited, in addition to the apparently global recruitment of $\mathrm{BF}$ cholinergic neurons by reinforcers (Hangya et al., 2015). It is also important to determine whether the functions of $\mathrm{BF}$ neurons are mediated by direct projections to the neocortex or via indirect projections to other subcortical targets, such as the thalamus (Parent et al., 1988; Jourdain et al., 1989; Bickford et al., 1994; Gritti et al., 1998), amygdala (Unal et al., 2015) and hypothalamus and brainstem (Freund and Meskenaite, 1992; Gritti et al., 1994, 1997, 2006; Henny and Jones, 2008; McKenna et al., 2013). Future studies will need to define the behavioral correlates of distinct neuronal populations in the BF, as well as address how different types of information arrives at the $\mathrm{BF}$, how the information is processed locally in the BF circuit, and how such information influences downstream activity in the cerebral cortex. These endeavors will help us understand how information about attention, learning, motivational salience, and arousal converge and interact in this underexplored nexus of the brain. Ultimately, this information will be crucial in designing specific treatments for disorders that affect $\mathrm{BF}$ function, such as coma (Brown et al., 2010), sleep disorders (Brown et al., 2012), dementia (Cummings and Benson, 1984), Alzheimer's disease (Whitehouse et al., 1982; Grothe et al., 2012), and normal cognitive aging (Gallagher and Colombo, 1995). 


\section{References}

Arroyo S, Bennett C, Aziz D, Brown SP, Hestrin S (2012) Prolonged disynaptic inhibition in the cortex mediated by slow, non- $\alpha 7$ nicotinic excitation of a specific subset of cortical interneurons. J Neurosci 32:3859-3864. CrossRef Medline

Avila I, Lin SC (2014a) Motivational salience signal in the basal forebrain is coupled with faster and more precise decision speed. PLoS Biol 12: e1001811. CrossRef Medline

Avila I, Lin SC (2014b) Distinct neuronal populations in the basal forebrain encode motivational salience and movement. Front Behav Neurosci 8:421. CrossRef Medline

Bakin JS, Weinberger NM (1996) Induction of a physiological memory in the cerebral cortex by stimulation of the nucleus basalis. Proc Natl Acad Sci U S A 93:11219-11224. CrossRef Medline

Barnes R, Jones MR (2000) Expectancy, attention, and time. Cogn Psychol 41:254-311. CrossRef Medline

Baxter MG, Bucci DJ (2013) Selective immunotoxic lesions of basal forebrain cholinergic neurons: twenty years of research and new directions. Behav Neurosci 127:611-618. CrossRef Medline

Bear MF, Singer W (1986) Modulation of visual cortical plasticity by acetylcholine and noradrenaline. Nature 320:172-176. CrossRef Medline

Bennett C, Arroyo S, Berns D, Hestrin S (2012) Mechanisms generating dual-component nicotinic EPSCs in cortical interneurons. J Neurosci 32:17287-17296. CrossRef Medline

Bickford ME, Günlük AE, Van Horn SC, Sherman SM (1994) GABAergic projection from the basal forebrain to the visual sector of the thalamic reticular nucleus in the cat. J Comp Neurol 348:481-510. CrossRef Medline

Boyden ES, Zhang F, Bamberg E, Nagel G, Deisseroth K (2005) Millisecondtimescale, genetically targeted optical control of neural activity. Nat Neurosci 8:1263-1268. CrossRef Medline

Brashear HR, Zaborszky L, Heimer L (1986) Distribution of GABAergic and cholinergic neurons in the rat diagonal band. Neuroscience 17:439-451. CrossRef Medline

Brown EN, Lydic R, Schiff ND (2010) General anesthesia, sleep, and coma. N Engl J Med 363:2638-2650. CrossRef Medline

Brown RE, McKenna JT (2015) Turning a negative into a positive: ascending GABAergic control of cortical activation and arousal. Front Neurol 6:135. CrossRef Medline

Brown RE, Basheer R, McKenna JT, Strecker RE, McCarley RW (2012) Control of sleep and wakefulness. Physiol Rev 92:1087-1187. CrossRef Medline

Buzsaki G, Bickford RG, Ponomareff G, Thal LJ, Mandel R, Gage FH (1988) Nucleus basalis and thalamic control of neocortical activity in the freely moving rat. J Neurosci 8:4007-4026. Medline

Chubykin AA, Roach EB, Bear MF, Shuler MG (2013) A cholinergic mechanism for reward timing within primary visual cortex. Neuron 77:723735. CrossRef Medline

Côté PY, Sadikot AF, Parent A (1991) Complementary distribution of calbindin D-28k and parvalbumin in the basal forebrain and midbrain of the squirrel monkey. Eur J Neurosci 3:1316-1329. CrossRef Medline

Coull JT, Nobre AC (1998) Where and when to pay attention: the neural systems for directing attention to spatial locations and to time intervals as revealed by both PET and fMRI. J Neurosci 18:7426-7435. Medline

Crochet S, Petersen CC (2006) Correlating whisker behavior with membrane potential in barrel cortex of awake mice. Nat Neurosci 9:608-610. CrossRef Medline

Cummings JL, Benson DF (1984) Subcortical dementia. Review of an emerging concept. Arch Neurol 41:874-879. CrossRef Medline

DeLong MR (1971) Activity of pallidal neurons during movement. J Neurophysiol 34:414-427. Medline

Disney AA, Aoki C, Hawken MJ (2007) Gain modulation by nicotine in macaque v1. Neuron 56:701-713. CrossRef Medline

Duque A, Balatoni B, Detari L, Zaborszky L (2000) EEG correlation of the discharge properties of identified neurons in the basal forebrain. J Neurophysiol 84:1627-1635. Medline

Eggermann E, Kremer Y, Crochet S, Petersen CC (2014) Cholinergic signals in mouse barrel cortex during active whisker sensing. Cell Rep 9:16541660. CrossRef Medline

Everitt BJ, Robbins TW (1997) Central cholinergic systems and cognition. Annu Rev Psychol 48:649-684. CrossRef Medline

Ferezou I, Haiss F, Gentet LJ, Aronoff R, Weber B, Petersen CC (2007) Spa- tiotemporal dynamics of cortical sensorimotor integration in behaving mice. Neuron 56:907-923. CrossRef Medline

Freund HJ, Kuhn J, Lenartz D, Mai JK, Schnell T, Klosterkoetter J, Sturm V (2009) Cognitive functions in a patient with Parkinson-dementia syndrome undergoing deep brain stimulation. Arch Neurol 66:781-785. CrossRef Medline

Freund TF, Gulyás AI (1991) GABAergic interneurons containing calbindin D28K or somatostatin are major targets of GABAergic basal forebrain afferents in the rat neocortex. J Comp Neurol 314:187-199. CrossRef Medline

Freund TF, Meskenaite V (1992) gamma-Aminobutyric acid-containing basal forebrain neurons innervate inhibitory interneurons in the neocortex. Proc Natl Acad Sci U S A 89:738-742. CrossRef Medline

Froemke RC, Merzenich MM, Schreiner CE (2007) A synaptic memory trace for cortical receptive field plasticity. Nature 450:425-429. CrossRef Medline

Furuta T, Koyano K, Tomioka R, Yanagawa Y, Kaneko T (2004) GABAergic basal forebrain neurons that express receptor for neurokinin $\mathrm{B}$ and send axons to the cerebral cortex. J Comp Neurol 473:43-58. CrossRef Medline

Gallagher M, Colombo PJ (1995) Ageing: the cholinergic hypothesis of cognitive decline. Curr Opin Neurobiol 5:161-168. CrossRef Medline

Gavornik JP, Shuler MG, Loewenstein Y, Bear MF, Shouval HZ (2009) Learning reward timing in cortex through reward dependent expression of synaptic plasticity. Proc Natl Acad Sci U S A 106:6826-6831. CrossRef Medline

Gibbon J (1977) Scalar expectancy theory and Weber's law in animal timing. Psychol Rev 84:279-325. CrossRef

Goard M, Dan Y (2009) Basal forebrain activation enhances cortical coding of natural scenes. Nat Neurosci 12:1444-1449. CrossRef Medline

Gritti I, Mainville L, Jones BE (1993) Codistribution of GABA- with acetylcholine-synthesizing neurons in the basal forebrain of the rat. J Comp Neurol 329:438-457. CrossRef Medline

Gritti I, Mainville L, Jones BE (1994) Projections of GABAergic and cholinergic basal forebrain and GABAergic preoptic-anterior hypothalamic neurons to the posterior lateral hypothalamus of the rat. J Comp Neurol 339:251-268. CrossRef Medline

Gritti I, Mainville L, Mancia M, Jones BE (1997) GABAergic and other noncholinergic basal forebrain neurons, together with cholinergic neurons, project to the mesocortex and isocortex in the rat. J Comp Neurol 383: 163-177. CrossRef Medline

Gritti I, Mariotti M, Mancia M (1998) GABAergic and cholinergic basal forebrain and preoptic-anterior hypothalamic projections to the mediodorsal nucleus of the thalamus in the cat. Neuroscience 85:149-178. CrossRef Medline

Gritti I, Manns ID, Mainville L, Jones BE (2003) Parvalbumin, calbindin, or calretinin in cortically projecting and GABAergic, cholinergic, or glutamatergic basal forebrain neurons of the rat. J Comp Neurol 458:11-31. CrossRef Medline

Gritti I, Henny P, Galloni F, Mainville L, Mariotti M, Jones BE (2006) Stereological estimates of the basal forebrain cell population in the rat, including neurons containing choline acetyltransferase, glutamic acid decarboxylase or phosphate-activated glutaminase and colocalizing vesicular glutamate transporters. Neuroscience 143:1051-1064. CrossRef Medline

Grothe M, Heinsen H, Teipel SJ (2012) Atrophy of the cholinergic Basal forebrain over the adult age range and in early stages of Alzheimer's disease. Biol Psychiatry 71:805-813. CrossRef Medline

Gu Q, Singer W (1989) The role of muscarinic acetylcholine receptors in ocular dominance plasticity. EXS 57:305-314. Medline

Gu Z, Yakel JL (2011) Timing-dependent septal cholinergic induction of dynamic hippocampal synaptic plasticity. Neuron 71:155-165. CrossRef Medline

Gu Z, Lamb PW, Yakel JL (2012) Cholinergic coordination of presynaptic and postsynaptic activity induces timing-dependent hippocampal synaptic plasticity. J Neurosci 32:12337-12348. CrossRef Medline

Hangya B, Ranade SP, Lorenc M, Kepecs A (2015) Central cholinergic neurons are rapidly recruited by reinforcement feedback. Cell 162:11551168. CrossRef Medline

Hassani OK, Lee MG, Henny P, Jones BE (2009) Discharge profiles of identified GABAergic in comparison to cholinergic and putative glutamatergic basal forebrain neurons across the sleep-wake cycle. J Neurosci 29: 11828-11840. CrossRef Medline

Hasselmo ME, Sarter M (2011) Modes and models of forebrain cholinergic 
neuromodulation of cognition. Neuropsychopharmacology 36:52-73. CrossRef Medline

Henny P, Jones BE (2008) Projections from basal forebrain to prefrontal cortex comprise cholinergic, GABAergic and glutamatergic inputs to pyramidal cells or interneurons. Eur J Neurosci 27:654-670. CrossRef Medline

Hermanstyne TO, Kihira Y, Misono K, Deitchler A, Yanagawa Y, Misonou H (2010) Immunolocalization of the voltage-gated potassium channel Kv2.2 in GABAergic neurons in the basal forebrain of rats and mice. J Comp Neurol 518:4298-4310. CrossRef Medline

Herrero JL, Roberts MJ, Delicato LS, Gieselmann MA, Dayan P, Thiele A (2008) Acetylcholine contributes through muscarinic receptors to attentional modulation in V1. Nature 454:1110-1114. CrossRef Medline

Hescham S, Lim LW, Jahanshahi A, Blokland A, Temel Y (2013) Deep brain stimulation in dementia-related disorders. Neurosci Biobehav Rev 37: 2666-2675. CrossRef Medline

Hippenmeyer S, Vrieseling E, Sigrist M, Portmann T, Laengle C, Ladle DR, Arber S (2005) A developmental switch in the response of DRG neurons to ETS transcription factor signaling. PLoS Biol 3:e159. CrossRef Medline

Huertas MA, Hussain Shuler MG, Shouval HZ (2015) Heterogeneous cellular dynamics in a network trained to report reward timing. J Neurosci 35:12659-12672. CrossRef.

Hur EE, Zaborszky L (2005) Vglut2 afferents to the medial prefrontal and primary somatosensory cortices: a combined retrograde tracing in situ hybridization study. J Comp Neurol [Erratum (2005) 486:98-99] 483: 351-373. CrossRef Medline

Jones BE (2003) Arousal systems. Front Biosci 8:s438-s451. CrossRef Medline

Jones BE (2004) Activity, modulation and role of basal forebrain cholinergic neurons innervating the cerebral cortex. Prog Brain Res 145:157-169. CrossRef Medline

Jones BE (2005) From waking to sleeping: neuronal and chemical substrates. Trends Pharmacol Sci 26:578-586. CrossRef Medline

Jourdain A, Semba K, Fibiger HC (1989) Basal forebrain and mesopontine tegmental projections to the reticular thalamic nucleus: an axonal collateralization and immunohistochemical study in the rat. Brain Res 505: 55-65. CrossRef Medline

Kilgard MP, Merzenich MM (1998) Cortical map reorganization enabled by nucleus basalis activity. Science 279:1714-1718. CrossRef Medline

Kim T, Thankachan S, McKenna JT, McNally JM, Yang C, Choi JH, Chen L, Kocsis B, Deisseroth K, Strecker RE, Basheer R, Brown RE, McCarley RW (2015) Cortically projecting basal forebrain parvalbumin neurons regulate cortical gamma band oscillations. Proc Natl Acad Sci U S A 112:35353540. CrossRef Medline

Lee MG, Hassani OK, Alonso A, Jones BE (2005) Cholinergic basal forebrain neurons burst with theta during waking and paradoxical sleep. J Neurosci 25:4365-4369. CrossRef Medline

Letzkus JJ, Wolff SB, Meyer EM, Tovote P, Courtin J, Herry C, Lüthi A (2011) A disinhibitory microcircuit for associative fear learning in the auditory cortex. Nature 480:331-335. CrossRef Medline

Lin SC, Nicolelis MA (2008) Neuronal ensemble bursting in the basal forebrain encodes salience irrespective of valence. Neuron 59:138-149. CrossRef Medline

Lin SC, Gervasoni D, Nicolelis MA (2006) Fast modulation of prefrontal cortex activity by basal forebrain noncholinergic neuronal ensembles. J Neurophysiol 96:3209-3219. CrossRef Medline

Liu CH, Coleman JE, Davoudi H, Zhang K, Hussain Shuler MG (2015) Selective activation of a putative reinforcement signal conditions cued interval timing in primary visual cortex. Curr Biol 25:1551-1561. CrossRef Medline

McGaughy J, Everitt BJ, Robbins TW, Sarter M (2000) The role of cortical cholinergic afferent projections in cognition: impact of new selective immunotoxins. Behav Brain Res 115:251-263. CrossRef Medline

McKenna JT, Yang C, Franciosi S, Winston S, Abarr KK, Rigby MS, Yanagawa Y, McCarley RW, Brown RE (2013) Distribution and intrinsic membrane properties of basal forebrain GABAergic and parvalbumin neurons in the mouse. J Comp Neurol 521:1225-1250. CrossRef Medline

McLin DE 3rd, Miasnikov AA, Weinberger NM (2002) Induction of behavioral associative memory by stimulation of the nucleus basalis. Proc Natl Acad Sci U S A 99:4002-4007. CrossRef Medline

Mesulam MM, Van Hoesen GW (1976) Acetylcholinesterase-rich projections from the basal forebrain of the rhesus monkey to neocortex. Brain Res 109:152-157. CrossRef Medline
Mesulam MM, Mufson EJ, Wainer BH, Levey AI (1983) Central cholinergic pathways in the rat: an overview based on an alternative nomenclature (Ch1-Ch6). Neuroscience 10:1185-1201. CrossRef Medline

Metherate R, Weinberger NM (1989) Acetylcholine produces stimulusspecific receptive field alterations in cat auditory cortex. Brain Res 480: 372-377. CrossRef Medline

Metherate R, Cox CL, Ashe JH (1992) Cellular bases of neocortical activation: modulation of neural oscillations by the nucleus basalis and endogenous acetylcholine. J Neurosci 12:4701-4711. Medline

Meynert TH (1872) The brain of mammals. In: A manual of histology (Stricker S, ed), pp 650-766. New York: Wood.

Miasnikov AA, McLin D 3rd, Weinberger NM (2001) Muscarinic dependence of nucleus basalis induced conditioned receptive field plasticity. Neuroreport 12:1537-1542. CrossRef Medline

Miasnikov AA, Chen JC, Gross N, Poytress BS, Weinberger NM (2008) Motivationally neutral stimulation of the nucleus basalis induces specific behavioral memory. Neurobiol Learn Mem 90:125-137. CrossRef Medline

Moruzzi G, Magoun HW (1949) Brainstem reticular formation and activation of the EEG. Electroencephalogr Clin Neurophysiol 1:455-473. CrossRef Medline

Namboodiri VM, Huertas MA, Monk KJ, Shouval HZ, Hussain Shuler MG (2015) Visually cued action timing in the primary visual cortex. Neuron 86:319-330. CrossRef Medline

Nawaratne V, Leach K, Suratman N, Loiacono RE, Felder CC, Armbruster BN, Roth BL, Sexton PM, Christopoulos A (2008) New insights into the function of M4 muscarinic acetylcholine receptors gained using a novel allosteric modulator and a DREADD (designer receptor exclusively activated by a designer drug). Mol Pharmacol 74:1119-1131. CrossRef Medline

Nguyen DP, Lin SC (2014) A frontal cortex event-related potential driven by the basal forebrain. Elife 3:e02148. CrossRef Medline

Parent A, Paré D, Smith Y, Steriade M (1988) Basal forebrain cholinergic and noncholinergic projections to the thalamus and brainstem in cats and monkeys. J Comp Neurol 277:281-301. CrossRef Medline

Pinto L, Goard MJ, Estandian D, Xu M, Kwan AC, Lee SH, Harrison TC, Feng G, Dan Y (2013) Fast modulation of visual perception by basal forebrain cholinergic neurons. Nat Neurosci 16:1857-1863. CrossRef Medline

Poulet JF, Petersen CC (2008) Internal brain state regulates membrane potential synchrony in barrel cortex of behaving mice. Nature 454:881-885. CrossRef Medline

Poulet JF, Fernandez LM, Crochet S, Petersen CC (2012) Thalamic control of cortical states. Nat Neurosci 15:370-372. CrossRef Medline

Richardson RT, DeLong MR (1990) Context-dependent responses of primate nucleus basalis neurons in a go/no-go task. J Neurosci 10:25282540. Medline

Richardson RT, DeLong MR (1991) Electrophysiological studies of the functions of the nucleus basalis in primates. Adv Exp Med Biol 295:233252. CrossRef Medline

Rossi J, Balthasar N, Olson D, Scott M, Berglund E, Lee CE, Choi MJ, Lauzon D, Lowell BB, Elmquist JK (2011) Melanocortin-4 receptors expressed by cholinergic neurons regulate energy balance and glucose homeostasis. Cell Metab 13:195-204. CrossRef Medline

Salma A, Vasilakis M, Tracy PT (2014) Deep brain stimulation for cognitive disorders: insights into targeting nucleus basalis of meynert in alzheimer dementia. World Neurosurg 81:e4-e5. CrossRef Medline

Sarter M, Hasselmo ME, Bruno JP, Givens B (2005) Unraveling the attentional functions of cortical cholinergic inputs: interactions between signal-driven and cognitive modulation of signal detection. Brain Res Rev 48:98-111. CrossRef Medline

Sarter M, Parikh V, Howe WM (2009) Phasic acetylcholine release and the volume transmission hypothesis: time to move on. Nat Rev Neurosci 10:383-390. CrossRef Medline

Saunders A, Oldenburg IA, Berezovskii VK, Johnson CA, Kingery ND, Elliott HL, Xie T, Gerfen CR, Sabatini BL (2015) A direct GABAergic output from the basal ganglia to frontal cortex. Nature 521:85-89. CrossRef Medline

Semba K (2000) Multiple output pathways of the basal forebrain: organization, chemical heterogeneity, and roles in vigilance. Behav Brain Res 115: 117-141. CrossRef Medline

Shuler MG, Bear MF (2006) Reward timing in the primary visual cortex. Science 311:1606-1609. CrossRef Medline

Smith KS, Berridge KC, Aldridge JW (2011) Disentangling pleasure from 
incentive salience and learning signals in brain reward circuitry. Proc Natl Acad Sci U S A 108:E255-E264. CrossRef Medline

Thomson E, Lou J, Sylvester K, McDonough A, Tica S, Nicolelis MA (2014) Basal forebrain dynamics during a tactile discrimination task. J Neurophysiol 112:1179-1191. CrossRef Medline

Tindell AJ, Berridge KC, Zhang J, Peciña S, Aldridge JW (2005) Ventral pallidal neurons code incentive motivation: amplification by mesolimbic sensitization and amphetamine. Eur J Neurosci 22:2617-2634. CrossRef Medline

Tindell AJ, Smith KS, Berridge KC, Aldridge JW (2009) Dynamic computation of incentive salience: "wanting" what was never "liked." J Neurosci 29:12220-12228. CrossRef Medline

Tingley D, Alexander AS, Kolbu S, de Sa VR, Chiba AA, Nitz DA (2014) Task-phase-specific dynamics of basal forebrain neuronal ensembles. Front Syst Neurosci 8:174. CrossRef Medline

Unal CT, Pare D, Zaborszky L (2015) Impact of basal forebrain cholinergic inputs on basolateral amygdala neurons. J Neurosci 35:853-863. CrossRef Medline

Vong L, Ye C, Yang Z, Choi B, Chua S Jr, Lowell BB (2011) Leptin action on GABAergic neurons prevents obesity and reduces inhibitory tone to POMC neurons. Neuron 71:142-154. CrossRef Medline

Voytko ML (1996) Cognitive functions of the basal forebrain cholinergic system in monkeys: memory or attention? Behav Brain Res 75:13-25. CrossRef Medline

Voytko ML, Olton DS, Richardson RT, Gorman LK, Tobin JR, Price DL (1994) Basal forebrain lesions in monkeys disrupt attention but not learning and memory. J Neurosci 14:167-186. Medline

Walker LC, Price DL, Young WS 3rd (1989) GABAergic neurons in the primate basal forebrain magnocellular complex. Brain Res 499:188-192. CrossRef Medline

Whitehouse PJ, Price DL, Struble RG, Clark AW, Coyle JT, Delon MR (1982)
Alzheimer's disease and senile dementia: loss of neurons in the basal forebrain. Science 215:1237-1239. CrossRef Medline

Wilson FA, Rolls ET (1990a) Learning and memory is reflected in the responses of reinforcement-related neurons in the primate basal forebrain. J Neurosci 10:1254-1267. Medline

Wilson FA, Rolls ET (1990b) Neuronal responses related to reinforcement in the primate basal forebrain. Brain Res 509:213-231. CrossRef Medline

Wu H, Williams J, Nathans J (2014) Complete morphologies of basal forebrain cholinergic neurons in the mouse. Elife 3:e02444. CrossRef Medline

Yang C, McKenna JT, Zant JC, Winston S, Basheer R, Brown RE (2014) Cholinergic neurons excite cortically projecting basal forebrain GABAergic neurons. J Neurosci 34:2832-2844. CrossRef Medline

Zaborszky L (2002) The modular organization of brain systems. Basal forebrain: the last frontier. Prog Brain Res 136:359-372. CrossRef Medline

Zaborszky L, Csordas A, Mosca K, Kim J, Gielow MR, Vadasz C, Nadasdy Z (2015) Neurons in the basal forebrain project to the cortex in a complex topographic organization that reflects corticocortical connectivity patterns: an experimental study based on retrograde tracing and 3D reconstruction. Cereb Cortex 25:118-137. CrossRef Medline

Zhang F, Wang LP, Brauner M, Liewald JF, Kay K, Watzke N, Wood PG, Bamberg E, Nagel G, Gottschalk A, Deisseroth K (2007) Multimodal fast optical interrogation of neural circuitry. Nature 446:633-639. CrossRef Medline

Zhao S, Ting JT, Atallah HE, Qiu L, Tan J, Gloss B, Augustine GJ, Deisseroth K, Luo M, Graybiel AM, Feng G (2011) Cell type-specific channelrhodopsin-2 transgenic mice for optogenetic dissection of neural circuitry function. Nat Methods 8:745-752. CrossRef Medline

Zold CL, Hussain Shuler MG (2015) Theta oscillations in visual cortex emerge with experience to convey expected reward time and experienced reward rate. J Neurosci 35:9603-9614. CrossRef Medline 